\title{
Integrated Supply Chain Projects and multifunctional local development: the creation of a Perfume Valley in Tuscany
}

\author{
Silvia Scaramuzzi ${ }^{*}$ (D), Giovanni Belletti ${ }^{2}$ and Paola Biagioni ${ }^{2}$
}

\author{
${ }^{*}$ Correspondence: silvia. \\ scaramuzzi@unifi.it \\ ${ }^{1}$ Dipartimento di Scienze e \\ Tecnologie Agrarie, Alimentari, \\ Ambientali e Forestali, Università di \\ Firenze, Piazzale delle Cascine, 18, \\ 50144 Florence, Italy \\ Full list of author information is \\ available at the end of the article
}

\begin{abstract}
Marginal rural areas are undergoing major pressures from the effects of globalization, especially when no alternative has been found to conventional extensive agriculture and a lack of investments and vision squeezes the income of farmers. The objective of the paper is to show how Integrated Supply Chain Projects (Progetti Integrati di Filiera (PIF)), Italian rural policy tools funded in the framework of EU's Rural Development Policy, can integrate supply chain innovation and territorial integrated strategies, fostering a multifunctional development of marginal rural areas towards a newly discovered identity. The case study is the PIF "Flora Aromatica Santa Luce" funded by the Tuscany Regional Administration RDP in 2016. The project aims at creating a new supply chain of organic aromatic plants in the Santa Luce Valley (PI). The integration is based, on the one side, on the creation and valorization of the new supply chain product, represented by an organic cosmetic line made with lavender essential oil, and, on the other side, on the territorial development of the Valley, in an economic, social, environmental and touristic perspective. From a theoretical point of view, the approach used was based on the new rural development paradigm, assuming that the processes of broadening, deepening and regrounding, together compose the main axis of rural development. The canvas model was used in order to identify a business model for the new supply chain and the territorial development of the area, while, at the methodological level, a participatory action research (PAR) approach was adopted. Results show how a supply chain project (like a PIF) can enhance innovation and stable commercial relationships within the supply chain and support processes of vertical and horizontal coordination, but also stimulate extended territorial strategies supporting the integration processes between agriculture, processing and other economic activities following a territorial multifunctional development logic. At the same time, key benefits for the policymaker and local administrations can also be identified in particular for marginal rural areas where farmers and other local actors are weaker and collective action is more difficult. Thanks to the PAR approach, a PIF can stimulate participation of farmers to relevant RDP measures but also allow convergence of individual actions towards wider regional and local strategic objectives.
\end{abstract}

Keywords: Local development, Integrated Supply Chain Project, Multifunctionality, Rural development policy, Rural tourism, Business Model Canvas, Officinal plants, Lavender 


\section{Introduction}

Marginal rural areas are undergoing major pressures from the effects of globalization, especially when no alternative has been found to conventional extensive agriculture and a lack of investments and vision squeezes year by year the income of farmers.

The EU's Rural Development Policy 2014-2020 identifies as main strategic objectives the improvement of the competitiveness of agriculture, a sustainable management of natural resources and climate action and a balanced territorial development of rural economies and communities, including the creation and maintenance of employment (Reg. (EU) n. 1305/2013).

In order to increase the competitiveness of the agri-food and forestry system, Italy, in its 2014-2020 partnership agreement, has defined a strategy based, on the one hand, on the support for the organizational and structural growth of the single enterprises and, on the other hand, on the increase in investments in the agricultural, agri-food, forestry, aquaculture and fisheries supply chains (Dipartimento per lo Sviluppo e la Coesione economica 2014). Special attention is paid to the creation and consolidation of supply chains, which emphasizes the intention to give continuity to the positive experience of integrated supply chain design, the tool for the implementation of rural development interventions introduced by the National Strategic Plan (NSP) for the programming period of 2007-2013 (Cristiano and Tarangioli 2010).

The objective of this paper is to show how an Integrated Supply Chain Project (Progetto Integrato di Filiera (PIF)) can not only stimulate innovation in the supply chain, but at the same time activate a process of multifunctional development of a marginal rural area towards a newly discovered identity, as a tourist destination.

The case study is focused on Santa Luce Valley, a hilly area on the boundaries between the provinces of Pisa and Livorno, Italy. Its economy is still largely tied to conventional agriculture, which is the main production activity in these hills. Farms mainly produce oil, wine, honey and cereals. In Santa Luce, old traditions and many forgotten professions are still present, while the importance of tourism is very marginal, though being geographically positioned very close to Pisa and coastal marine resorts.

In particular, the case study analyses the Integrated Supply Chain Project "Flora Aromatica Santa Luce" funded by the Tuscany Regional Administration in 2016. The project aims at creating a new supply chain of organic aromatic plants in the Santa Luce Valley (PI). The integration is based on the creation and valorization of the new supply chain product, represented by an organic cosmetic line made with lavender essential oil, and, on the other side, on the territorial development of the Valley, in an economic, social, environmental and touristic perspective. The authors, as partners of the project, were involved in the building process of the supply chain project, providing for scientific expertise and methodological tools to producers and other actors involved. In this paper, we critically analyse the process and the results of this building process.

The paper starts from describing the theoretical approach and then goes in-depth into the case study description and main results, then end with a final discussion and main conclusions.

\section{Theoretical approach}

The Integrated Supply Chain Projects (PIFs) are formal agreements between the actors of an agro-industrial chain, instrumental for the creation and the consolidation of 
networks and of new governance forms aimed at solving specific problems and at managing, in an integrated way, relevant issues such as safety, quality and environmental protection. Partners are required to formally sign a supply chain agreement in which shared objectives and strategies are specified, but also obligations, roles and responsibilities of the individual actors. Fostering the integration of economic operators, PIFs aim to better coordinate the various chain rings, enhancing the market access of agricultural producers (Cristiano and Tarangioli 2010; D'Alessio 2010).

PIFs are promoted within the regional Rural Development Programmes (RDPs) funded by the European Agricultural Fund for Rural Development (EAFRD) in the wider framework of the partnership agreement between the Member State and the European Union. RDPs offer a set of measures that are usually singly activated through specific tender notices. On the contrary, PIFs are based on "multi-measure" tender notices, which have to be jointly applied for by specific partnerships. Regional administrations may decide to activate different measures, according to their regional strategies. ${ }^{1}$ This kind of tender notices allows to meet the specific needs of both the farming and manufacturing/retailing sectors involved while maintaining consistency between the project objectives and the regional strategy (Zezza 2016; European Network for Rural Development 2012).

The integration between the economic operators and the sharing of a development programme allows reducing the transaction costs related to the exchange of information and materials, thus improving the overall efficiency of the supply chain. The coordination of actors encourages faster dissemination of both information and innovation; the definition of stable supply chain relationships, instead, allows to meet the needs of the different stages of production and to obtain superior quality products. The repetition of commercial exchanges between the same parties has the further effect of reducing the risk of opportunistic behaviour within the supply chain (Ventura et al. 2011).

The strategic and systemic logic promoted by PIFs is able to increase and multiply the impact of the single interventions in support of the agricultural and forestry sector. In fact, through this tool, it is possible to realize a critical mass of investments that individually the supply chain operators would not be able to guarantee (Cristiano and Tarangioli 2010). PIFs therefore facilitate the achievement of general objectives of innovation, modernization, restructuring and improvement of the quality of production in the agri-food sector and encourage, at the same time, adequate employment and territorial development (Ventura et al. 2011; D'Alessio 2010). The integrated design is by its nature complex, requiring intense concertation of the parties, both in the programming phase and in the project implementation phase. The involvement of actors belonging to different sectors requires further efforts in defining specific procedures, management and levels of accountability in project implementation for each area of intervention. Inadequate or insufficient organizational efforts are likely to produce duplications, fragmented policies, delays, conflicts and unsatisfactory results; therefore, a

\footnotetext{
${ }^{1}$ In the case of Tuscany, the PIF call activated the measures: 3.1 "Participation to quality standards for agricultural and food products"; 3.2 "Information and promotion activity"; 4.1 "Support to farm investment"; 4.2 "Investments for processing, marketing and/or development of agricultural products"; 6.4 "Support to investment for the creation and development of non-agricultural activities"; 8.6 "Support to investment in forest technologies, processing, mobilization and commercialization of forest products"; 16.2 "Support to pilot and cooperation projects".
} 
careful assessment of the actual opportunities that this tool can offer in the context of reference and the attitude of the single actors to the planning and sharing of development strategies is required (Zumpano 2007; Tarangioli 2010).

The complexity of PIFs is also reflected in the formal administrative procedures required that attain at the presentation of the project phase, implementation phase, reporting phase and final control. This complexity, besides disorienting potential beneficiaries, often disincentives the regional administrations themselves from adopting this type of integrated design tool (Tarangioli 2010). In the programming period for rural development 2007-2013, in fact, there were only 14 regions that allocated the resources to the PIF (Zezza 2016).

What is particularly relevant for marginal rural areas is that PIFs may generate competitive advantages not only for the supply chain but also for the whole territory, where the activities of the supply chain are located. This is true in particular when the supply chain is short and concentrated in a specific territory, the initiative is based on local specific resources, and when this territory is a marginal rural area with few opportunities and poor dynamic. A horizontal and multifunctional integration of other actors of the territory is therefore requested.

Theories of rural development inspired by Ploeg (Ploeg and Renting 2004; Wiskerke and van der Ploeg 2004) highlight this need for integration by speaking about redefinition of farm boundaries (Ventura and Milone 2004; Knickel and Renting 2000) according to three dimensions: deepening (more value added can be generated per unit of product through such mechanisms as quality production, on farm processing, new short circuits), broadening (inclusion of new agricultural-linked activities that are located on the interface between society, community, landscape and biodiversity, such as agro-tourism, energy production and delivery of different services within the rural economy) and regrounding. The latter, in particular, advocates for a re-articulation of relationships of the firm with its context, with other firms and other actors in the local rural space, allowing for new forms of value creation. This is, for example, the case of wine routes (Brunori and Rossi 2000). Diversification and especially agri-tourism development are implicit in the objectives of the PIFs, taking into account that they activate specific measures dedicated to these goals in order to support farmers in investing in such activities.

Successful rural tourism is characterized by a tight link between the territorial capital and the services offered in the rural location (Belletti and Berti 2011). Territorial capital can be defined as the stock of specific resources (tangible and intangible) that can be used by people belonging to a specific community and that are available for mobilization in projects (Belletti and Berti 2011). Rural territorial capital can be broken down into seven main components (Berti 2009; Belletti and Berti 2011): the environmental capital, the economic capital, the human capital, the social capital, the institutional capital, the cultural capital and the symbolic capital.

In rural destinations, stakeholders are supposed to be highly interrelated (Baggio et al. 2010) and are often characterized by a high competition of small firms that are obliged to cooperate in order to integrate the services offered in a complex tourist product (Belletti et al. 2013; Tolstad 2014). An integrated approach in the construction of the product (Cawley and Gillmor 2008; Kastenholz and Fingueiredo 2014) and in the design of the governance of the system is therefore essential (Saxena and Ilbery 2008; Belletti et al. 2013). 
The need to design organizational and governance structures to enact commercial opportunities (George and Bock 2011) leads to the identification of a business model for the system. In order to analyse and improve the organization and governance of the system, the authors make use of the Business Model Canvas (BMC) as a strategic tool that helps to define the organizations' business models according to a customeroriented approach (Osterwalder and Pigneur 2010). BMC allows, with a simple and effective visual language, to enhance the logic that an organization adopts to create, offer and capture value, with special reference to revenues, reputation and identity.

The BMC is a graphic scheme consisting of nine blocks, each corresponding to one of the following core elements of the business model:

1. "Customers" are the market segments for which the organization wants to create value through targeted proposals.

2. "Value proposition" describes the set of products and services designed to create value for the identified customer segment and how they are proposed to the target. The value proposition is the heart of the model and outlines a complete picture of the tangible and intangible features of the enterprise's supply, which aims to meet the needs or solve the problems of its customers.

3. "Channels" describe the means through which the value proposition reaches the selected customer segments (communication channels, distributors or sales channels). They represent the meeting place between the enterprise and the recipients of the offer; therefore, they must be selected in the most effective way always taking into account the characteristics of the market segment to which they are addressed.

4. "Customer relationship" describes the modalities with which the enterprise considers to acquire and to retain customers and the type of relationship that wants to build with them.

5. "Revenue streams" summarize the revenue streams that come from a value proposition for which customers are willing to pay a price. It then defines the actual ways in which the enterprise captures value.

6. "Key resources" are the tangible and intangible assets indispensable to delineate and offer the value proposition (human, intellectual, physical, financial resources).

7. "Key activities" are the main activities that the company has to implement to determine its competitive advantage.

8. "Key partners" are the external strategic partners that provide the organization with key resources or that realize key activities for their business model.

9. "Cost structure" describes the costs of implementing the business model, essentially related to the last three blocks described.

In the definition of Osterwalder and Pigneur, "a business model describes the rationale of how an organisation creates, delivers, and captures value" (Osterwalder and Pigneur 2010, p. 14). Pölling et al. (2017) state that BMC permits researchers to analyse the organization and performances of farms, both economically and socially. It also allows for the definition and comparison of key success factors, barriers, competitors and business ideas and innovations. In the Perfume Valley project, in order to identify a business model for the new supply chain and the territorial development of the area, 
we therefore thought BMC could be a correct tool. As a matter of fact, the model has a customer-oriented perspective and is a useful framework to identify key resources, activities, partners and target customers, for the design of a common strategy for the supply chain product and the entire Perfume Valley territory. Furthermore, the value proposition, at the centre of the BMC, describes how to offer and capture the value itself. The immediacy of the visual scheme allows to focus the attention on the key elements of the business, to highlight their reciprocal relationships at a qualitative level, to easily identify any critical issues by speeding up the problem-solving processes (Osterwalder and Pigneur 2010; Osterwalder et al. 2014; Amanullah et al. 2015).

\section{Methodology}

In order to apply the BMC, we adopted a participatory action research (PAR) approach with the goal of involving the local community in sharing and analysing their environment on the one side and to identify their strategic goals and plan their actions on the other side. In particular, PAR seeks to understand and improve a specific context or situation by changing it (Chambers 1994; Baum et al. 2006) thus generating an ongoing collective and self-reflective action research process, in collaboration with academic researchers and made by, with and for people affected by a particular problem. It helps them create awareness and emphasizes co-learning and active participation among stakeholders, so that they can become active and leading subjects for the development and transformation of their immediate surroundings and reality (Kindon et al. 2007; Kindon et al. 2009; Padilla and Ramos Filho 2012). Thus, plural, shared and participative knowledge production becomes an instrument of social and/or organizational transformation (Baum et al. 2006; Greenwood et al. 1993).

The following phases were followed: (a) critical analysis of the existing literature; (b) 20 in-depth interviews with local stakeholders in order to identify the main actors to be involved in the process, strengths and weaknesses of past projects and possible perspective strategies to be carried out; (c) a direct online survey submitted to 253 firms, associations and other public and private stakeholders; and (d) 5 knowledge circles (Mittendorff et al. 2006).

The sample of 253 firms, association and other public and private stakeholders is the result of a dedicated activity carried out within the project aiming at building a database of all the local private and public actors, related to tourism, cultural and wellness activities and mapping them. The municipalities involved in the PIF and the neighbouring ones (Santa Luce, Orciano Pisano, Castellina Marittima, Casciana Terme-Lari, Chianni, Crespina Lorenzana, Pomarance, Fauglia and Riparbella) have been considered. The main online search engines (i.e. Google), numerous tourist web portals and institutional sites of municipalities and local tourist offices were examined in order to reconstruct the panorama of current and potential tourist services supply in this hilly area of Tuscany. The relevant data were identified in each municipality and divided into 4 broad categories: (1) accommodation services-both hotels and non-hotel; (2) food and beverage-catering, farms and commercial activities of agri-food products; (3) other local businesses and associations-special focus on activities related to wellness (wellness centres, spas), commercial activities related to cosmetic and herbal products and sports activities; and (4) local public administrations. 
The sample is almost identifiable with the universe of firms and actors existing in the territory. The online survey was based on two questionnaires prepared for two different groups of activities: the first consisting of accommodation facilities, catering, farms and commercial activities, and the second one for personal services; sports; recreational, cultural and association activities; travel agencies and tour operators; passenger transport; car hire; consortia; and public institutions.

The "knowledge circles" were structured and moderated by two facilitators who shortly presented the thematic field and then lead the group discussion, stimulating the acquisition of information and knowledge sharing about (a) the "territorial capital" ${ }^{2}$ of the locality, (b) defining shared development strategies for the valorization of the capital and (c) sharing a strategic agenda with mutual engagement.

\section{The case study: Flora Aromatica Santa Luce project}

The "Flora Aromatica Santa Luce" project was funded by the Tuscany Region through the 2015 tender notice for "Integrated Supply Chain Projects".

The project involves 16 actors for a total cost of investments of 1.1 million euros and a public funding of 689.000 euros. The project leader is the processing firm Flora, specialized in the production of aromatherapy products and natural and organic cosmetics. Eleven farmers, 2 research institutes, 1 farmers' organization and 1 commercial firm specialized in marketing of cosmetic products are participating.

The project aims to contribute to the economic, social, environmental and tourist valorization of the hilly area on the boundaries between the provinces of Pisa and Livorno, Italy. The area has undergone a very relevant progressive depopulation after the Second World War, and the economy is still largely tied to conventional agriculture, which is the main production activity of these hills. The main agricultural productions in the area are olive oil, wine, honey and cereals. In Santa Luce, old traditions and many forgotten professions are still present, while the importance of tourism is very marginal, though being geographically positioned very close to Pisa and coastal marine resorts.

The main actions of the projects are (a) the partial (from 1 to 2 ha per farm) and progressive reconversion of the agricultural area, currently devoted to the conventional cultivation of cereals and organic and biodynamic crops of officinal plants for the extraction of essential oils of great value; (b) the construction of a new local supply chain for the extraction of high-quality essential oils and production of cosmetics; and (c) an integrated local development of the "Perfume Valley".

Flora is committed to purchasing all the inflorescences produced by the farms' partners of the project for the production of essential oils to be used for the creation of a new cosmetic line for 8 years at market price. The strength and innovation of the "Flora Aromatica" project consists, therefore, in the establishment of a completely new agro-industrial chain for the territory of the Tuscany region with broad market prospects.

The economic development of actors directly involved in the chain is not the only goal of the project, which also aims to generate positive externalities over the entire territory relying on the concept of multifunctionality in agriculture. The choice of

${ }^{2}$ See paragraph 2 for the definition of the territorial capital. 
lavender as the main crop is justified, not only by the high market demand for its essential oil, but also by the extraordinary landscaping value of its blooms, which can become a source of tourist attraction. The multifunctional goal of the PIF is to give birth to the "Perfume Valley", creating a new symbolic capital of the rural area at the borders between the provinces of Pisa and Livorno and valorize it as a new tourist destination. All the farmers involved in the PIF are also interested in the development of such a multifunctional goal (many of them have an agri-tourism, but also recognize the importance of direct selling, besides wine and olive oil, also lavender products together with visual and emotional experiences to valorize them), the processing firm leading the project (especially for the increase of the brand image and direct selling) and of course the commercial firm acting as a marketing strategy developer. In this paper, we will focus our attention in particular on the results of the creation process of the Perfume Valley (funded by measure 16.2 "Support to pilot and cooperation projects"): a new thematic and "multi-experiential" tourist destination, aiming at integrating the supply chain development with the territorial valorization of the area.

\section{Results}

The Business Model Canvas was adopted as an operational guideline in order to structure the information and results of the project.

In terms of value proposition, the "Perfume Valley" was identified as a thematic and "multi-experiential" tourist destination, based on the concept of an integrated and multifunctional product territory built around the lavender. More in detail, we shared with the actors the idea of structuring the valorization of the Valley and the communication message on the multiple tourist experiences that can be carried out in the territory, thanks to the integration of different actors that supply diversified goods and services, in a territory whose specific identity is based on the lavender.

Through the PAR approach, we identified the resources of the territory aiming at increasing the awareness of local actors about the potential of the area and sharing knowledge in order to build an integrated touristic product. The actors involved in the process were, in terms of number and diversification of activities, far beyond the ones benefiting from the PIF financial support and identified in Fig. 1 within the left rectangle. In fact, in order to share the project goals, the perspective of territorial enhancement and the main characteristics of the business plan, we activated and stimulated the actors of the territory through in-depth interviews submitted to the key stakeholders (coming from different sectors and the local public administrations), online surveys and focus groups (see par. 2 for methodology).

Great appreciation and proactivity were immediately manifested by the actors of the PIF in order to activate other actors through mail and word of mouth so as to make the following focus groups as effective as possible in terms of qualitative and quantitative participation. The first focus group was just devoted to farmers involved in the project and the processor leading the project in order to stimulate their involvement and commitment to the goals. The second focus group involved both farmers belonging to the chain and not, but interested in enhancing tourism, and the project leader, in order to identify, in a participatory way, the components of "territorial capital" of the locality; to share the "experiences" each of them can offer to the tourists; and to define shared development strategies for enhancing the value of the capital. The third, fourth and 


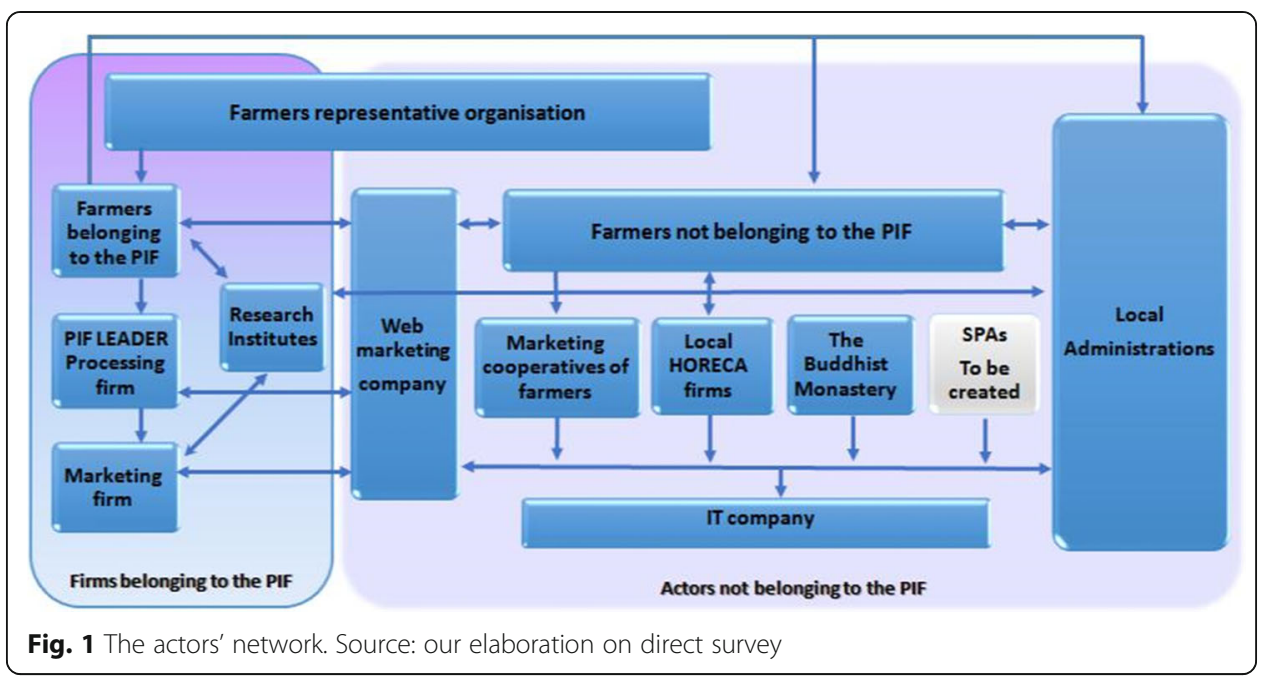

fifth focus groups were enlarged inviting all other firms belonging to different sectors (Horeca, IT and Web marketing) and mapped in the cited database. The enlargement was aimed at defining shared development strategies for enhancing the value of the capital and sharing a strategic agenda with mutual engagement. This led to clear enthusiasm, but limits were identified in terms of time and budget, owing to the length of the processes for reaching a critical mass of actors in order to promote synergically outside and give continuity to the project. Nevertheless, we identified different positions of the actors towards the implementation of the strategy. The partners of the supply chain of the integrated project totally shared the objectives and were available to invest in terms of human and financial resources. Many farms not belonging to the partnership were also quite involved in the adoption of collective and synergic actions, while only few actors belonging to the Horeca sector decided to invest resources. As for the local administrations, they supported the strategic initiatives through participatory and information actions, but no funding was dedicated to the implementation of the strategy.

As a result, in order to give continuity to the promotional project, only few actors decided to co-fund the submission of an application for further funding based on an open call of the Tuscany Regional Administration: aiming at IT empowerment, web marketing promotion through innovative, experiential techniques based on storytelling and visual involvement on a dedicated platform and app development. The platform will share and promote the results of the territorial capital analysis. The actors benefiting from the new funding together will start again a process for sharing a territorial identity and building authentic tourist experiences to be proposed to their guests.

In order to further deepen the knowledge of the actors of the territory and, in particular, their attitude to experiential tourism, their IT competence and their equipment and networking propensity, we made an online survey to a total sample of 223 structures and activities related to tourism. From the 28 answers obtained from the questionnaire addressed to the first group of activities, it was noted an excellent predisposition of respondents to the idea of creating both an "itinerary/theme offer of the Santa Luce Valley" that involves all the actors interested in tourism on the territory $(92.9 \%)$ and a territorial brand (92.9\%). In the latter case, however, the willingness of 
almost half of the respondents to join it depended on the presence of incentives (4\%) and on the access rules (44\%); $73.1 \%$ of respondents also considered it useful to develop a portal and/or a territorial app to integrate, enhance and promote the offer of the Santa Luce Valley.

The actors' network was finally composed by all the 11 farmers belonging to the project partnership and new farmers interested in networking, 4 municipalities, 1 restaurant, 6 hotels and other accommodation firms, 1 local marketing cooperative for farm products, 1 farmers' organization, 1 marketing company, 1 IT company and 1 web marketing agency (Fig.1).

During the participatory processes for the construction of the new experiences to be proposed to the tourists, we shared with the local actors the Pine and Gilmore (1999) model for the economy of experiences. The latter was the basis of the categorization we made, with special reference to the need for higher or lower physical involvement of the tourists in more active or passive experiences. Four categories were identified (Pine and Gilmore 1999): entertainment, education, aesthetic and escapist, which are referred to as the "4Es". The 4Es form permeable quadrants that reflect positions along two continua of experiences. Particular attention was paid to those experiences related to lavender, such as aromatherapy massages in the lavender fields, bike/horse riding/ hiking tours among the hillsides in bloom or exclusive dinners in the fields. These "experiential paths", adding to the activities related to rurality and wellness already present in the area, should be able to meet the needs of the tourist target attracted by the Valley (Fig. 2).

After defining the existing and potential tourist experiences with the actors of the territory, the analysis has moved to a segmentation of the tourism market, based on motivations that can drive tourists to these areas: a qualitative variable deemed sufficient to outline homogeneous groups from the point of view of preferences and the type of experience sought. From the intersection of the three types of tourism considered (rural, experiential and well-being), a main target, called "experiential rural wellness", and three other niches defined by the overlapping of two of the three macro-segments of

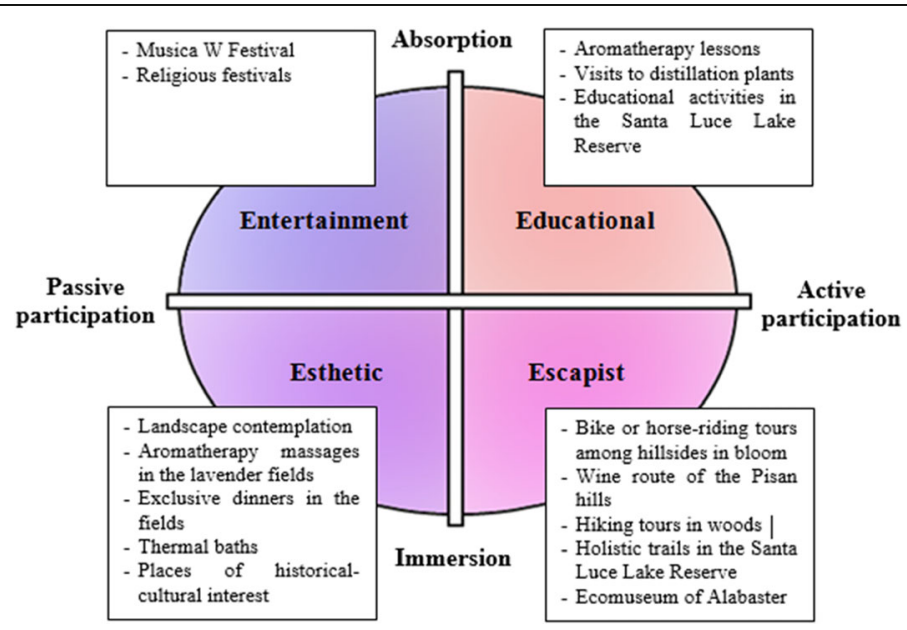

Fig. 2 Experiences categorization in the Perfume Valley. Source: our elaboration on Pine and Gilmore (1999) model 
tourism have been identified: "rural wellness", "rural experience" and "wellness experience" (Fig. 3).

Starting from the characteristic features of the four segments, the value proposition has been defined: besides proposing experiential activities, it aims at promoting the organic cosmetic line produced by the "Flora Aromatica" chain, presenting it to tourists in the "courtesy" version in the accommodation facilities and the wellness centres of the area, as well as local shops for tourist souvenirs, pharmacies and perfumeries. Here, will end the experiential circle of the tourist who, after testing the quality of the product, will buy it in order to recreate the atmosphere and the scents of the Santa Luce Valley also at home.

The development and management of this offer require organizational, relational and operational activities and considerable coordination efforts among the actors in the area. For this reason, among the "key activities", it was proposed to sign a network contract by the companies involved in the "Flora Aromatica" chain and by the activities of the tertiary sector such as receptive and complementary structures, defining a new model of economic integration on the territory. The network programme encompasses a series of key activities including the creation of an integrated web platform, designed to promote and commercialize tourism products, and an app, designed to create support for and engagement of the tourists. In order to maintain positive and lasting relationships over time and to retain tourists' loyalty, web marketing activities are also expected to cope with online communication, which is increasingly important in the tourist industry.

The management of network activities requires the intervention of a destination manager, a professional who, thanks to his know-how and his specific skills, can become the leading managerial figure for the design, implementation and promotion of the territorial offering, also taking a facilitator role in the relationships between network participants and the network and its stakeholders. The choice of the network to rely on a specialized consultant such as the destination manager is strategic in order to constantly seek an improvement in the quality and competitiveness of the tourist offer. The burden of sustaining the costs of the activities, resources and key partners for the realization of the "Perfume Valley" is at the expense of the network, which uses for this

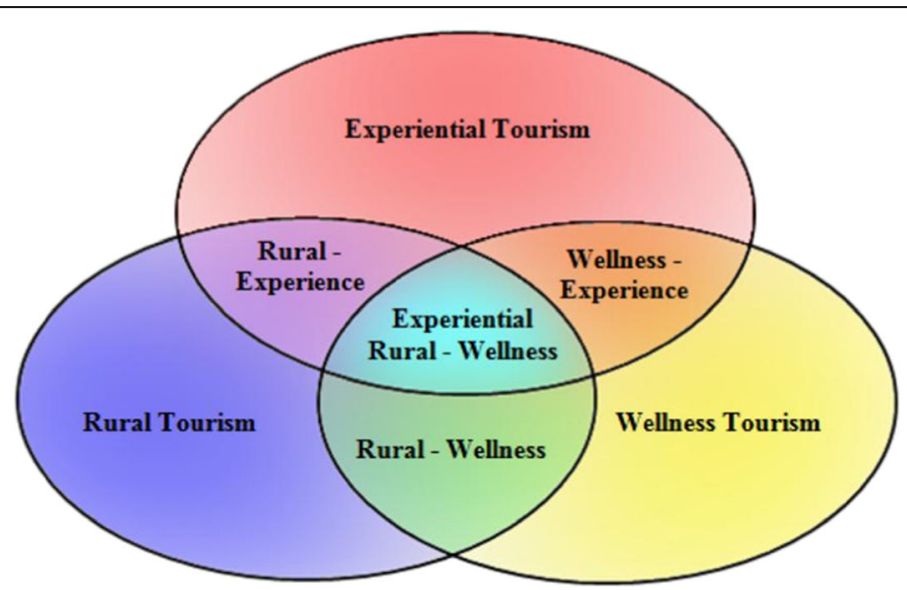

Fig. 3 Segmentation of the tourist market attracted by the Perfume Valley. Source: our elaboration 
purpose its own funds, powered by both income from affiliation-both from external funding and from fees charged on the products-and services offered.

To encourage a consistent promotion and commercialization of the value proposition and the definition of a unified image of the territory, the creation of a collective brand specially designed for the "Perfume Valley" has been proposed to the local actors by the research team leading and coordinating the participatory processes. The actors shared the need of a territorial brand to be constructed in order to convey in an attractive way, not only the distinctive features of the territory, but also the eco-sustainability of the local supply system, built around the lavender and the product of the "Flora Aromatica" chain. The actors agreed that the trademark should be granted to all those who work in the territory in the field of tourism and agriculture and to those companies in the industrial, commercial and artisanal sectors that carry out activities compatible with its disciplines.

Figure 4 presents the BM Canvas as a visual synthesis of the results of the process carried out at the territorial level in order to identify a development strategy for the Perfume Valley. In a customer-oriented approach, the image offers the contents of the nine blocks identified by the actors involved in order to create, offer and capture value. For the creation of the value, we report the key partners, activities and resources, on the left part of the figure, while on the right part, we describe the customer segmentation, the main marketing channels and the customer relationship. A synthesis of the main investments to be done to capture value in terms of expected revenues and results is also provided at the bottom.

\section{Discussion}

The PIF project was concluded in October 2018. It is difficult at present to assess its economic impact both in the supply chain management and in the integrated territorial development of the area. In fact, the first collection of lavender from the farmers will be in July 2019; when given the extraction values, it will be possible to evaluate the profitability of the lavender crop in the Perfume Valley on the basis of the yield in essential oils and fixed and variable costs undertaken. Only then it will be possible to start assessing the return on investments (ROI) carried out.

Of course, other positive externalities have to be considered.

The creation of the "Perfume Valley" and its unitary management leads to an enrichment of the rural territorial capital in its social, environmental, human and symbolic components, also promoting the recovery of local traditions and the rediscovery of a common sense of belonging between local actors involved in an integrated valuecreating system.

This system allows the construction of a sustainable territorial model capable of selffeeding by linking rurality, typical products and tourism development, and of meeting both the needs of a specific tourist demand and the economic development of a rural area with great potential.

The BMC proved to be very useful as an operational model in order to identify how to create, offer and capture value in the territory. "Although the Canvas has a simple structure, it forms a complex system of interdependencies between the different elements" (Henriksen et al., 2012, p. 34). Blasi et al. (2016) describe the Business Model Canvas as an effective tool for public authorities, even small municipalities, as it is able 


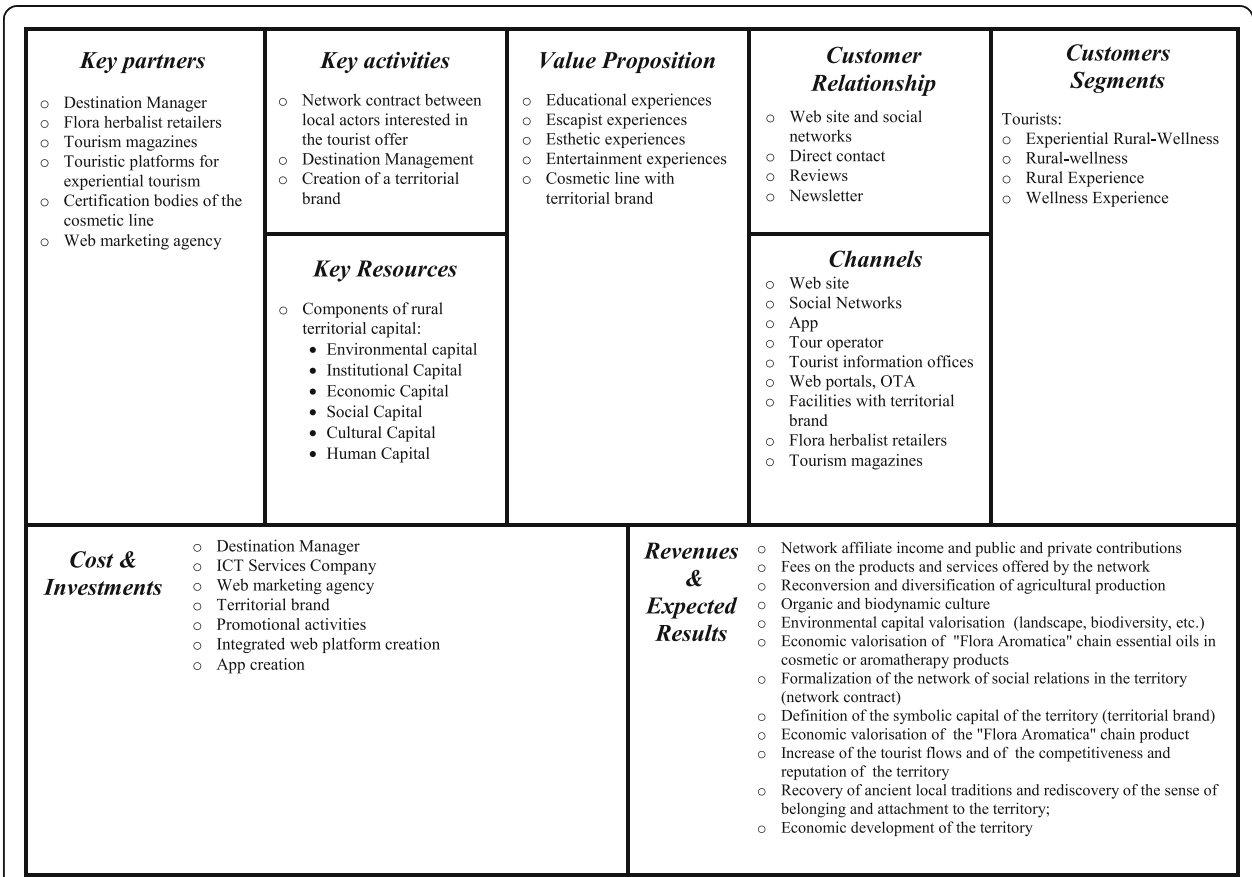

Fig. 4 The Perfume Valley Canvas Business Model. Source: our elaboration on a direct survey of Osterwalder and Pigneur (2010) model

to combine local development with environmental protection and the health of children, as referred to the implementation of school canteens. Torquati et al. (2015) prove $\mathrm{BMC}$ to be useful for describing, interpreting and comparing practices of social agriculture that are quite diversified in form, organization, objectives and type of user reached, and they finally propose its use for all contexts of multifunctional agriculture. This research allowed to prove its validity also for the identification of a common value proposition and valorization strategy for an entire territory, with special reference to its enhancement as a rural tourism destination.

The project gives an important contribution to the existing discussion on how participatory ideas and practices are increasingly developed and implemented in both agriculture and sustainable rural development (Padilla and Ramos Filho 2012; Pretty 1995). The action research carried out demonstrates how PAR can actualize the dialogue between scientific knowledge and practical and local knowledge at the level of scientific production aiming at strengthening the endogenous potential and find solutions to the problems in the agrarian field and in rural contexts (Padilla and Ramos Filho 2012; Idziak, Majewski, Zmyślony 2015).

The participatory methods used have proved to be very useful for the business model construction and validation, especially for reaching an increased shared awareness of the territorial capital, the potential and tools for its valorization and the construction of the identity for the destination (Paül et al. 2016; Presenza et al. 2014), based on the new supply chain development of cultivations and final products.

Results also give a contribution to the present debate on how an Integrated Supply Chain Project (as PIF is) can be a successful policy tool on the beneficiary side by enhancing stable commercial relationships within the supply chain (Ventura et al. 2011), stimulating and supporting processes of vertical and horizontal integration, facilitating 
the introduction of innovation in the supply chain and also reach a territorial multifunctional development (Ventura et al. 2011; D'Alessio 2010).

\section{Conclusions}

The paper proves how multi-level approaches (vertical and horizontal), through diversified funding sources (multi-measure and multi-fund), can be integrated to reach common goals among different actors within a territory.

To this respect, a PAR methodology proves to be particularly useful in order to share information, ideas, value propositions and strategies, thus generating an ongoing collective and self-reflective process and participative knowledge production as a tool for social and/or organizational transformation.

Both the multi-level and multi-actor approaches combined with the PAR are at the basis of the multifunctional development of the territory that the project has fostered. As a matter of fact, the rural tourism product has been designed as a rural experiential product: engaging, integrated, accessible, friendly, authentic, lively and linked to the territory, as a result of a systemic territorial offer, and dynamics, based on a plurality of goods, services, information, tourist attractions, environmental and cultural supply from the individual companies and the local administrations. In this perspective, local actors are not considered as independent elements, but interconnected units as part of a complex system of relationships that emerges from the territory.

Results show how PIFs can enhance innovation and stable commercial relationships within the supply chain and support processes of vertical and horizontal coordination, but also stimulate extended territorial strategies supporting integration processes between agriculture, processing and other economic activities following a territorial multifunctional development logic.

PIFs have demonstrated to be tools that can go far beyond the vertical integration of firms. They are extremely versatile for building not only economic capital but through intense relations, an important social capital that is particularly useful in stimulating innovation and creativity, around which enlarging goals and perspective planning. Both private and public stakeholders may play a significant role in the construction of the actors' network.

At the same time, key benefits for the policymaker and local administrations can also be identified in particular for marginal rural areas where farmers and other local actors are weaker and collective action is more difficult. Thanks to the PAR approach, a PIF can stimulate participation of farmers to relevant RDP measures but also allow convergence of individual actions towards wider regional and local strategic objectives.

\section{Abbreviations}

BMC: Business Model Canvas; EAFRD: European Agricultural Fund for Rural Development; PAR: Participatory action research; PIF: Integrated Supply Chain Project; RDP: Rural Development Program

\section{Acknowledgements}

This paper has been selected as one of the best papers of the First joint SIDEA-SIEA Conference in Bisceglie/Trani (1316 September 2017). It has been accepted for publication in this journal following the usual review process. 


\section{Funding}

The Integrated Supply Chain Project "Flora Aromatica Santa Luce" was funded by the Tuscany Regional Administration on the 2014-2020 Rural Development Funds - Call "Progetti integrati di Filiera - PIF annualità 2015", approved through Decree n. 2359, dated 26 May 2015 "Regulation (UE) n. 1305/2013"

\section{Availability of data and materials}

The data that support the findings of this study are available on request from the corresponding author [SS]. The data are not publicly available due to them containing information that could compromise research participant consent.

\section{Competing interests}

The authors declare that they have no competing interests.

\section{Author details}

${ }^{1}$ Dipartimento di Scienze e Tecnologie Agrarie, Alimentari, Ambientali e Forestali, Università di Firenze, Piazzale delle Cascine, 18, 50144 Florence, Italy. ${ }^{2}$ Dipartimento di Scienze per l'Economia e l'Impresa, Università di Firenze Via delle Pandette, 9, 50127 Florence, Italy.

Received: 12 August 2018 Accepted: 23 December 2019

Published online: 21 January 2020

\section{References}

Amanullah ANAA, Aziz NFA, Abd Hadi FNH, Ibrahim J (2015) Comparison of Business Model Canvas (BMC) among the three consulting companies. Int J Comput Sci Inf Technol Res 3(2):462-471

Baggio R, Scott N, Cooper C (2010) Improving tourism destination governance: a complexity science approach. Tour Rev 65(4):51-60

Baum F, MacDougall C, Smith D (2006) Participatory action research. J Epidemiol Community Health 60(10):854-857

Belletti G, Berti G (2011) Turismo, ruralità e sostenibilità attraverso l'analisi delle configurazioni turistiche. In: Pacciani A (ed) Aree rurali e configurazioni turistiche. Differenziazione e sentieri di sviluppo in Toscana, Milano, Franco Angeli

Belletti G, Berti G, Brunori G, Marescotti A, Rovai M (2013) Is rural tourism sustainable? A reflection based on the concept of 'rural tourism configurations. In: Figueiredo E, Raschi A (eds) Fertile Links? Connections between tourism activities, socioeconomic contexts and local development in European rural areas. Firenze University Press, Florence, pp 93-104

Blasi G, Caruso A, Viganò E (2016) Participatory design of a sustainable school canteen through the development of a Business Model Canvas. [Progettazione partecipata di una mensa scolastica sostenibile mediante lo sviluppo di un Business Model Canvas]. Economia Agro-Alimentare 18(3):319-344

Berti G (2009) Valorizzazione della diversità e sviluppo nella campagna contemporanea: la costruzione del web rurale in Lunigiana, [Dissertation thesis], Alma Mater Studiorum Università di Bologna. Dottorato di ricerca in Cooperazione internazionale e politiche per lo sviluppo sostenibile, 20 Ciclo.

Brunori G, Rossi A (2000) Synergy and coherence through collective action: some insights from wine routes in Tuscany. Sociol Rural 40(4):409-423

Cawley M, Gillmor DA (2008) Integrated rural tourism: concepts and practice, in Annals of Tourism Research, Volume 35 (2). Elsevier Ltd, Oxford

Chambers R (1994) Participatory rural appraisal (PRA): challenges, potentials and paradigm. World Dev 22(10):1437-1454

Cristiano S, Tarangioli S (2010) Valutazione on-going e progettazione integrata di filiera tra sfide e opportunità di sviluppo dei settori agricolo e forestale. Agriregionieuropa 6(22) https://agriregionieuropa.univpm.it/it/content/article/31/22/ valutazione-going-e-progettazione-integrata-di-filiera-tra-sfide-e-opportunita.

D’Alessio M (2010) La progettazione integrata di filiera. Una guida per l'implementazione dello strumento a livello nazionale. http://www.reterurale.it/flex/cm/pages/ServeBLOB.php/L/TT/IDPagina/2612. Accessed 24 July 2017.

Dipartimento per lo Sviluppo e la Coesione economica (2014) Accordo di partenariato 2014-2020 Italia. http://www. agenziacoesione.gov.it/it/AccordoPartenariato/. Accessed 24 July 2017.

European Network for Rural Development (2012) The integrated supply-chain projects in Emilia Romagna Region, Italy. http://enrd.ec.europa.eu/enrd-static/fms/pdf/244C53E6-DA24-D7D6-6F57-7B9CA2F1AE41.pdf. Accessed 24 July 2017.

George G, Bock AJ (2011) The business model in practice and its implications for entrepreneurship research. Entrepreneurship Theory and Practice 35(1):83-111

Greenwood DJ, Whyte WF, Harkavy I (1993) Participatory action research as a process and as a goal. Hum Relat 46(2):175

Henriksen K, Bjerre M, Maria Almasi A, Damgaard-Grann E (2012) Green Business Model Innovation - Conceptualization report, Copenhagen: Nordic Council of Ministers.

Idziak W, Majewski J, Zmyślony P (2015) Community participation in sustainable rural tourism experience creation: a longterm appraisal and lessons from a thematic villages project in Poland. J Sustain Tour 23(8-9):1341-1362

Kastenholz E, Fingueiredo E (2014) Rural tourism experiences. Land, sense and experience-scapes in quest of new tourist spaces and sustainable community development. Rev Turismo Patrimonio Cult 12(3):511-514

Kindon S, Pain R, Kesby M (2009) Participatory action research. In: International encyclopaedia of human geography 2009, pp 90-95. https://doi.org/10.1016/B978-008044910-4.00490-9

Kindon SL, Pain R, Kesby M (2007) Participatory action research approaches and methods: connecting people, participation and place. Routledge studies in human geography. Routledge, London

Knickel K, Renting H (2000) Methodological and conceptual issues in the study of multifunctionality and rural development. Sociol Rural 40(4):512-528

Mittendorff K, Geijsel F, Hoeve A, de Laat M, Nieuwenhuis L (2006) Communities of practice as stimulating forces for collective learning. J Work Learn 18(5):298-312

Osterwalder A, Pigneur Y (2010) Business model generation: a handbook for visionaries, game changers, and challengers. Wiley, Hoboken 
Osterwalder A, Pigneur Y, Bernarda G, Smith A (2014) Value proposition design: how to create products and services customers want. Wiley, Hoboken

Padilla MC, Ramos Filho LO (2012) Participatory action research initiatives to generate innovations towards a sustainable agriculture: a case study in Southern Spain. In: Barbier M, Elzen B (eds) System innovations, knowledge regimes, and design practices towards transitions for sustainable agriculture. INRA [online], posted online November 20,2012. http://inra-dam-front-resources-cdn.brainsonic.com/ressources/afile/246879-c218b-resource-system-innovationsknowledge-regimes-and-design-practices-towards-transitions-for-sustainable-agriculture.html.

Paül V, Trillo-Santamaría JM, Pérez-Costas P (2016) Action research for tourism planning in rural areas? Examining an experience from the from the Couto Mixto (Galicia, Spain). Geogr Res 54(2):153-164

Pine J, Gilmore J (1999) The experience economy: work is theatre \& every business a stage. Harvard Business School Press, Boston

Ploeg JD, Renting H (2004) Behind the 'redux': a rejoinder to David Goodman. Sociol Rural 44(2):234-242

Pölling B, Prados MJ, Torquati B, Giacchè G, Recasens X, Paffarini C, Alfranca O, Lorleberg W (2017) Business models in urban farming: comparative analysis of case studies from Italy, Spain, and Germany. Moravian Geogr Rep 25(3):166-180

Presenza A, Micera R, Splendiani, Del Chiappa G (2014) Stakeholder e-involvement and participatory tourism planning: analysis of an Italian case study. Int J Knowl Based Dev 5(3):311-328

Pretty JN (1995) Participatory learning for sustainable agriculture. World Dev 23(8):1247-1263

Saxena G, Ilbery B (2008) Integrated rural tourism: a border case study. Ann Tour Res 35(1):233-254

Tarangioli S (2010) I progetti integrati: le criticità di una procedura innovativa della politica di sviluppo rurale 2007-2013. Agriregionieuropa 6(21) https://agriregionieuropa.univpm.it/it/content/article/31/21/i-progetti-integrati-le-criticita-di-unaprocedura-innovativa-della-politica.

Tolstad HK (2014) Development of rural-tourism experiences through networking: an example from Gudbrandsdalen, Norway. Norwegian J Geogr 68(2):111-120

Torquati B, Tancini C, Paffarini C, Illuminati R (2015) Empirical survey on business models of kindergarten farms. Agric Food Econ 3:25. https://doi.org/10.1186/s40100-015-0043-4

Ventura F, Diotallevi F, Ricciardulli N, Berletti M (2011) Evaluation of policy measures for agri-food networks in Italian rural development programmes. In: Working paper $122^{\circ}$ Seminario EAAE "Evidence-based agricultural and rural policy making: methodological and empirical challenges of policy evaluation", Ancona, 17-18 Feb 2011

Ventura F, Milone P (2004) Novelty as redefinition of farm boundaries. In: Wiskerke JSC, van der Ploeg JD (eds) Seeds of transition: essays on novelty production, niches and regimes in agriculture. Royal Van Gorcum, Assen

Wiskerke JSC, van der Ploeg JD (eds) (2004) Seeds of transition: essays on novelty production, niches and regimes in agriculture. Royal Van Gorcum, Assen

Zezza A (2016) L'esperienza dei Progetti integrati di filiera: esperienze nel settore cerealicolo. Agriregionieuropa 12(44) https:// agriregionieuropa.univpm.it/it/content/article/31/44/lesperienza-dei-progetti-integrati-di-filiera-esperienze-nel-settore.

Zumpano C (2007) L'approccio integrato nelle politiche di sviluppo rurale: strumenti e modalità di attuazione. Agriregionieuropa 3(9) https://agriregionieuropa.univpm.it/it/content/article/31/9/lapproccio-integrato-nelle-politiche-disviluppo-rurale-strumenti-e-modalita-di.

\section{Publisher's Note}

Springer Nature remains neutral with regard to jurisdictional claims in published maps and institutional affiliations.

\section{Submit your manuscript to a SpringerOpen ${ }^{\circ}$ journal and benefit from:}

- Convenient online submission

- Rigorous peer review

- Open access: articles freely available online

- High visibility within the field

- Retaining the copyright to your article

Submit your next manuscript at $\boldsymbol{\nabla}$ springeropen.com 